\title{
A COMPARISON OF WEIGHT LOSS AND C ANALYSIS METHODS IN DETERMINING ORGANIC MATTER CONTENT IN SRI LANKAN SOILS
}

\author{
DAL Leelamanie*, TDP Liyanage and IMLV Rajarathna \\ Department of Soil Science, Faculty of Agriculture, University of Ruhuna, Mapalana, Kambu- \\ rupitiya 81100 , Sri Lanka
}

Accepted: $27^{\text {th }}$ September 2016

\begin{abstract}
Determination of organic matter in soils and sediments is typically requested with contaminant analysis as a part of ecological risk assessments. However, reliable and sensitive methods are required to enable the research and extension work to substantiate the expected outcome. The purpose of this study is to provide a comparison between weight loss and carbon (C) analysis methods in determining soil organic matter (SOM) content considering their usability with potential merits and demerits. Soil samples were collected from 20 locations representing various agro-ecological regions ranging from Jaffna to Matara, Sri Lanka. The samples were analyzed for the SOM content using the Walkley-Black (WB), hydrogen peroxide digestion $\left(\mathrm{H}_{2} \mathrm{O}_{2}\right)$, and loss on ignition (LOI) methods. The SOM content by different methods were compared using $C$ conversion factors of 1.724, 2.2, and 3.3 for the WB method. The SOM contents determined by $\mathrm{H}_{2} \mathrm{O}_{2}$ and the WB methods showed linear relationships (moderate correlation) with those determined by LOI method, where the coefficients of determination $\left(R^{2}\right)$ were 0.58 and 0.61, respectively. The LOI method provided the highest or comparably similar SOM content with the $\mathrm{H}_{2} \mathrm{O}_{2}$ and the WB methods except at very low SOM contents. Use of C conversion factors 2.2 and 3.3 made SOM content estimated by WB method closer to values obtained by $\mathrm{H}_{2} \mathrm{O}_{2}$ and LOI methods, respectively.

Key words: Carbon analysis, hydrogen peroxide digestion, loss on ignition, soil organic matter, Walkley-Black method
\end{abstract}

\section{INTRODUCTION}

Organic matter in soils and sediments is widely distributed over the earth's surface in almost all terrestrial and aquatic environments (Schnitzer, 1978). The importance of soil organic matter (SOM) in supplying nutrients, contributing to cation exchange capacity, and improving soil structure is already well recognized. Organic matter content of the soil is used to adjust nitrogen, sulfur, herbicide, and/ or lime recommendations in many parts in the world. Presence of organic matter is also known to be an important factor in calculating loading rates for sewage sludge and other wastes (Bertucci and Salvador, 1992) and stimulating non-wetting conditions in soil particles (Leelamanie and Karube, 2009) and aggregates (Leelamanie et al., 2013; Leelamanie and Karube, 2014a,b).

The SOM comprises an accumulation of partially disintegrated and decomposed plant and animal residues and different other organic

*Corresponding author: leelamanie@soil.ruh.ac.lk compounds synthesized by the soil microbes as the decaying of these materials occurs (Brady and Weil, 2010). Soil humus or the humic material is a heterogeneous mixture of organic compounds formed by degradation and synthesis of SOM. Soil humus makes up about $60-80 \%$ of the SOM (Eash et al., 2015), whereas the remaining part comprises less stable and partially decomposed organic residues. It is the stable fraction of SOM with varying levels of $\mathrm{C}$ storage (Velichko et al., 2010) and relatively high resistance to microbial attack (Prusty and Azeez, 2005).These variations affect the $\mathrm{C}$ content in SOM, use of a single value as the $\mathrm{C}$ conversion factor would be inappropriate. This knowledge has led to development of several values for the conversion factor depending on the soil type and the depth (Perie and Ouimet, 2007).

The determination of the SOM content is an essential part of any site characterization. Soil and sediment total organic carbon (TOC) determinations are typically requested with con- 
taminant analysis as part of an ecological risk assessment. Several simple laboratory techniques, which do not require sophisticated laboratory equipment, are presently being used for estimating the organic matter content of the soil. All these techniques are based on various assumptions that would directly affect the accuracy and the consistency of the results. Organic matter determinations can basically be classified into two groups. (1) Determination of some constituent that is found in a relatively constant percentage of soil organic matter such as nitrogen and Carbon (C); (2) weight loss on removal of the organic matter from the mineral fraction by digestion with $\mathrm{H}_{2} \mathrm{O}_{2}$, ignition, and ignition after decomposition of silicates. Most SOM contents are derived from organic $\mathrm{C}$ because the quantitative determination of SOM is expected to have uncertainties related with high variability and accuracy (Nelson and Sommers, 1982).

Organic $\mathrm{C}$ analysis is reasonably accurate using the traditional Walkley and Black (1934) technique. Walkley-Black (WB) digestion technique in general uses a conversion factor of 1.724 (related with the $58 \% \mathrm{C}$ in $\mathrm{OM}$ ) to convert organic $\mathrm{C}$ to organic matter. As it is assumed that only about $76-77 \%$ of the total organic matter is oxidized (Rowell, 2000; Walkley and Black, 1934), a multiplying factor of 1.33 is typically used to correct for this incomplete digestion (Rowell, 2000). Determination of the SOM content considering the weight loss by burning at high temperature is known to be the loss on ignition (LOI) method. Ratnayake et al., (2007) reported that the LOI method can be used as a quick and simple technique in chemical fractionation and quantification of organic matter for Sri Lankan Cambisols, compared with conventional extraction methods and better when large numbers of samples are to be analyzed. The digestion with hydrogen peroxide $\left(\mathrm{H}_{2} \mathrm{O}_{2}\right)$ removes the organic matter in the sample through oxidation. Robinson (1922) proposed to use $\mathrm{H}_{2} \mathrm{O}_{2}$ in the mechanical analysis of soils aiming to destroy the organic matter in soils, although the removal of organic matter is not complete. The $\mathrm{H}_{2} \mathrm{O}_{2}$ digestion method does not involve the use of an empirical factor or burning at high temperature as in the WB or LOI methods.

All these three techniques have different kinds of limitations. Although the WB method has conventionally been considered to be the standard method for the estimation of the organic matter content of agricultural soil samples, it is not a well-adapted for the rapid analysis of a large number of samples. It makes errors with soils containing high levels of $\mathrm{Mn}$ and cannot address the measurement of charcoal in many soils (Kimble et al., 2000). There are serious concerns about the routine use of this procedure because it uses Dichromate as one of the major reagents, which is identified to be highly toxic and Class-1 carcinogens which with a serious risk to the human health. Metal compounds such as $\mathrm{Cr}^{4+}$ are reduced intra cellularly to stable $\mathrm{Cr}^{3+}$, which can directly interact with DNA leading to mutations (Belpomme et al., 2007). The LOI method is a technique that can be considered causing no hazards to human health and environment with the added advantage of being comparatively simpler. However, different laboratories use various temperatures for the burning, giving rise to variable and inconsistent results. Ball (1964) suggested that use of low temperatures (below $400^{\circ} \mathrm{C}$ ) would reduce the extent of structural water losses from clays. However, this has been questioned because such low temperatures lead to very long analysis times and incomplete burning of SOM producing underestimated organic matter contents (Howard and Howard, 1990). Temperatures between 400 and $430^{\circ} \mathrm{C}$ are found not to show significantly bias results for SOM analysis in calcareous soils (Ben-Dor and Banin, 1989). It is further demonstrated that the presence of calcium carbonate in soils did not cause errors in LOI results at $430^{\circ} \mathrm{C}$ (Davies, 1974). Comparison estimated SOM contents by the LOI at 400 and $430^{\circ} \mathrm{C}$ with those obtained by $\mathrm{WB}$ and $\mathrm{H}_{2} \mathrm{O}_{2}$ methods would be important for Sri Lankan conditions where maintaining instruments such as $\mathrm{C} / \mathrm{N}$ coders is becoming less affordable. 
However, it is necessary to compare the SOM contents obtained by these different techniques to understand their merits and demerits considering Sri Lankan soils. The purpose of this study was to provide a comparison between most commonly used three laboratory test procedures (WB, LOI, and $\mathrm{H}_{2} \mathrm{O}_{2}$ methods) for determining organic matter content in soils, considering their usability and potential merits and demerits.

\section{MATERIALS AND METHODS}

Different 20 soil samples were selected representing various agro-ecological regions of the country, where the locations were ranged from Jaffna to Matara, Sri Lanka. The collected soils were belong to great soil groups Hapludults, Rhodustalfs, ultrmafic derived soil, Natraqulfs, Tropaquents and Tropofluvents. The bulk soil samples were collected from typical home gardens from a depth of 0-5 cm. Sampling was done during the period May-August, 2014. Three laboratory test procedures that are commonly used in determining organic matter content in soils were carried out to determine the SOM contents.

\section{Walkley-Black (WB) procedure}

The soil samples were air-dried and passed through a $2 \mathrm{~mm}$ sieve to remove coarser materials. For the test, $0.5 \mathrm{~g}$ of finely ground soil samples were digested by $0.2 \mathrm{M} \mathrm{K}_{2} \mathrm{Cr}_{2} \mathrm{O}_{7}$ solution and concentrated $\mathrm{H}_{2} \mathrm{SO}_{4}$ under laboratory conditions $\left(28 \pm 1{ }^{\circ} \mathrm{C}\right.$ and $75 \pm 5 \%$ relative humidity) in three replicates. After $30 \mathrm{~min}$ of digestion, the sample mixture was treated with $85 \%$ orthophosphoric acid to avoid interferences from $\mathrm{Fe}^{3+}$ ions in the medium. Then the samples were titrated against ferrous ammonium sulfate in the presence of diphenylamine indicator to determine the remaining dichromate. The SOM content was calculated by multiplying the organic $\mathrm{C}$ content of the soil sample by the Van Bemmelen factor of
1.724 (Nelson and Sommers, 1982). The value was multiplied by 1.33 to correct for incomplete digestion of C (Rowell, 2000)

\section{Loss on ignition (LOI) method}

A 15-g sub sample of the air-dried soil was oven dried to remove the remaining hygroscopically bound moisture from the soils and weighed. The oven dried soils were kept in the muffle furnace at $400-430^{\circ} \mathrm{C}$ for $6 \mathrm{~h}$ for the complete ignition of the organic matter in the soil. After the ignition, the soils samples were cooled in desiccators, weighed, and the organic matter content was gravimetrically determined using the loss of weight between oven-dried and burned samples.

\section{The hydrogen peroxide $\left(\mathrm{H}_{2} \mathrm{O}_{2}\right)$ digestion method}

Sub samples of $10 \mathrm{~g}$ from each air-dried soil samples were treated with $50 \mathrm{ml}$ of $\mathrm{H}_{2} \mathrm{O}_{2}$ in evaporation dishes. The evaporating dishes were kept on a steam bath to provide heat for the acceleration of the reaction process. During the heating process, the samples were regularly stirred until the frothing ceases and the samples get bleached color. Once the digestion process is completed, the samples were dried at $105{ }^{\circ} \mathrm{C}$, cooled in a desiccator, and weighed. All the weights of samples were corrected for the moisture content using ovendrying of subsamples prior to the organic matter calculation. The SOM content was then calculated considering the weight loss by organic matter digestion.

\section{Statistical Analysis}

The data were tested for normality with Shapiro-Wilk test, where the null hypothesis was accepted at $p>0.05$. Statistical analysis was done with linear regression and ANOVA with mean separation using least significant difference test. Standard error of the regression models were checked and the significance was determined at $\mathrm{p}>0.05$. 


\section{RESULTS AND DISCUSSION}

The SOM contents determined by WB, $\mathrm{H}_{2} \mathrm{O}_{2}$, LOI methods are presented in Figure 1. Results showed that when the organic matter content in soil exceeded about $6 \mathrm{~g} / 100 \mathrm{~g}$ LOI method provided significantly higher organic matter contents compared with other two techniques. Since we found this difference is demarcating, the SOM contents determined by $\mathrm{WB}, \mathrm{H}_{2} \mathrm{O}_{2}$, and LOI methods are expressed in two sub figures, one below $6 \mathrm{~g} / 100 \mathrm{~g}$ (Figure $1 \mathrm{a}$ ), and the second beyond $6 \mathrm{~g} / 100 \mathrm{~g}$ (Figure $1 b)$, considering the SOM contents measured by the LOI method as the base.

Determinations of organic matter contents of different soil samples showed variations among the different techniques used. The SOM contents determined by LOI method showed a wide range $(1-12 \mathrm{~g} / 100 \mathrm{~g})$ for the tested samples. For most of the tested soil samples, the LOI method provided the highest or comparably similar organic matter contents with the $\mathrm{H}_{2} \mathrm{O}_{2}$ and the WB methods. The WB showed a trend to provide high or statistically similar SOM contents with other two methods when the organic matter level determined by the other methods were below $2 \mathrm{~g} / 100 \mathrm{~g}$.

It was interesting to find that SOM content of the same sample that observed to be above $10 \mathrm{~g} / 100 \mathrm{~g}$ when estimated by the LOI method

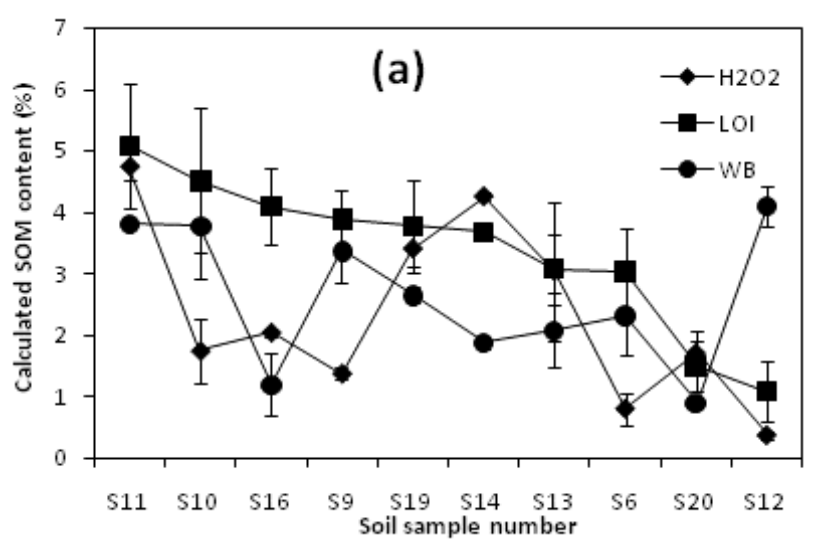

appeared to be below $6 \mathrm{~g} / 100 \mathrm{~g}$ when estimated by the other two methods. This agrees with the restrictions of the WB method, where the limit for measuring organic matter content without highly affecting the accuracy is approximately 6\% (Mylavarapu et al., 2014). The $\mathrm{H}_{2} \mathrm{O}_{2}$ method was found to provide almost comparable organic matter contents with WB method. Figures 2 and 3show the scatterplots and the regression lines for the correlation between the SOM content determination results from the three methods. There were linear relationships (moderate correlation), where the coefficient of determination $\left(\mathrm{R}^{2}\right)$ ranged between 0.58 and 0.61 .

In the WB method, the $\mathrm{Cr}^{4+}$ is reduced to $\mathrm{Cr}^{3+}$ reacting with $\mathrm{SOM}$ releasing $\mathrm{CO}_{2}$, which is measured using titration considering colorimetric changes. The WB procedure has been identified to lead to an incomplete oxidation of organic $\mathrm{C}$ and to particularly poor for digesting elemental $\mathrm{C}$ forms. A multiplying factor of 1.33 was used in this study to correct assuming $77 \%$ recovery. Studies have shown that the recovery of organic $\mathrm{C}$ using the WB procedure ranges from 60 to $86 \%$ with a mean recovery being around $76 \%$ (Walkley and Black, 1934). One reason for low SOM values in the present study compared with LOI method might be incomplete digestion of $\mathrm{C}$ with recovery levels below $77 \%$.

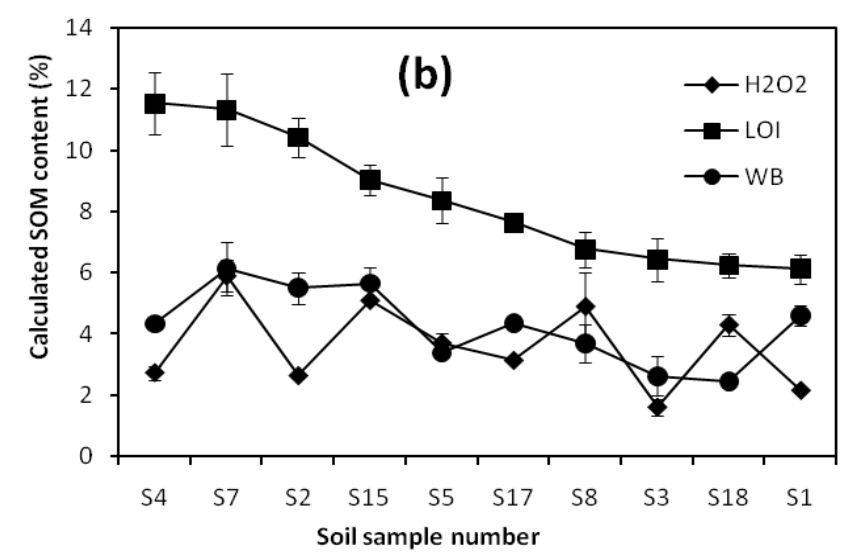

Figure 1: The soil organic matter (SOM) contents determined by Walkley-Black (WB), hydrogen peroxide $\left(\mathrm{H}_{2} \mathrm{O}_{2}\right)$, and Loss on ignition (LOI) methods. (a) Samples with SOM contents below $6 \%$ in all methods; (b) Samples with SOM contents beyond $6 \%$ at least in one method. 
Furthermore, the WB technique requires a conversion factor to convert organic $\mathrm{C}$ to organic matter, which is in general considered to be of 1.724 (Van Bemmelen factor that assumes a $58 \% \mathrm{C}$ in SOM). However, it is been recognized that the value of this conversion factor might range from 1.6 to 3.3 for different soils (Nelson and Sommers, 1982), because the percentage of $\mathrm{C}$ in the organic matter of different soils varies widely depending on the types of the organic matter.

Rowell (2000) reported that the low SOM contents related with WB method compared

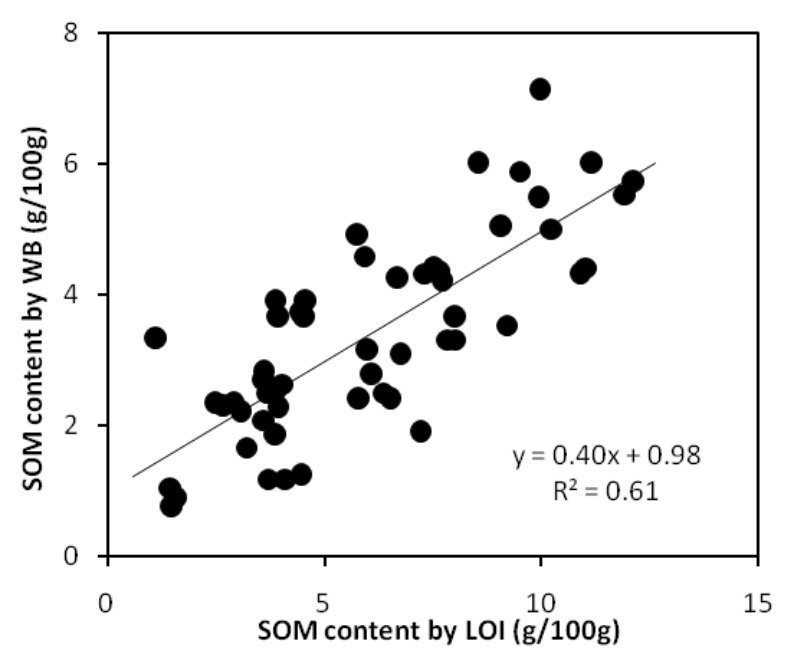

Figure 2: The relation between the soil organic matter (SOM) contents determined by Walkley-Black (WB) and Loss on ignition (LOI) methods. to the LOI method is in part due to the use of 1.724 as the conversion factor to calculate organic matter from organic carbon. He further explained that the positive bias in results can be eliminated if a factor of 2.2 is used. For the better understanding of the SOM contents related with the value of the $\mathrm{C}$ conversion factor, the relations of SOM determined with $\mathrm{WB}$ and those determined with LOI and $\mathrm{H}_{2} \mathrm{O}_{2}$ were predicted using the linear regression equations. Relations between the SOM contents as determined by WB and LOI, and WB and $\mathrm{H}_{2} \mathrm{O}_{2}$ methods that are predicted using the

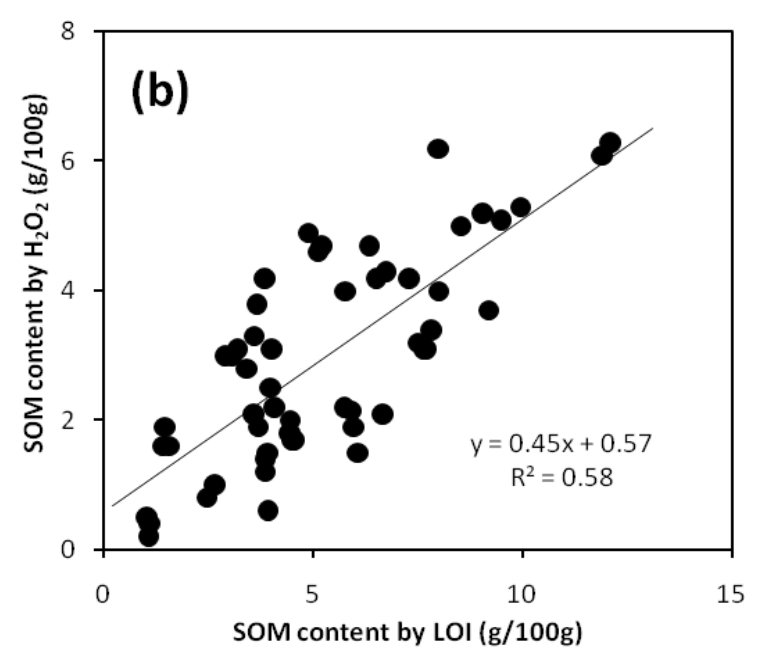

Figure 3: The relation between the soil organic matter (SOM) contents determined by hydrogen peroxide $\left(\mathrm{H}_{2} \mathrm{O}_{2}\right)$ and Loss on ignition (LOI) methods.

Table 1: Important physico-chemical properties of soil

\begin{tabular}{|c|c|c|c|c|c|c|c|}
\hline \multirow{2}{*}{$\begin{array}{c}\mathrm{C} \\
\text { conversion } \\
\text { Factor }\end{array}$} & \multirow{2}{*}{ model } & \multirow{2}{*}{$\mathrm{R}^{2}$} & \multicolumn{2}{|c|}{$\begin{array}{c}\text { independent } \\
\text { variable }\end{array}$} & \multicolumn{2}{|c|}{ intercept } & \multirow{2}{*}{$\begin{array}{c}\text { Standard error } \\
\text { overall }\end{array}$} \\
\hline & & & $\begin{array}{c}\text { Standard } \\
\text { error }\end{array}$ & $\mathrm{P}$ & $\begin{array}{l}\text { Standard } \\
\text { error }\end{array}$ & $\mathrm{p}$ & \\
\hline 1.724 & $\mathrm{H}_{2} \mathrm{O}_{2}=0.45 \mathrm{LOI}+0.57$ & 0.58 & 0.05 & $2.29 \mathrm{E}-11$ & 0.32 & 0.045 & 1.04 \\
\hline 1.724 & $\mathrm{WB}=0.40 \mathrm{LOI}+0.98$ & 0.61 & 0.04 & $2.49 \mathrm{E}-12$ & 0.29 & 0.001 & 0.94 \\
\hline 2.2 & $\mathrm{WB}=0.51 \mathrm{LOI}+1.26$ & 0.61 & 0.06 & $2.49 \mathrm{E}-12$ & 0.37 & 0.001 & 1.20 \\
\hline 3.3 & $\mathrm{WB}=0.76 \mathrm{LOI}+1.88$ & 0.61 & 0.08 & $2.49 \mathrm{E}-12$ & 0.56 & 0.001 & 1.80 \\
\hline 1.724 & $\mathrm{WB}=0.84 \mathrm{H}_{2} \mathrm{O}_{2}+0.18$ & 0.45 & 0.15 & $4.84 \mathrm{E}-06$ & 0.60 & 0.759 & 1.22 \\
\hline 2.2 & $\mathrm{WB}=1.07 \mathrm{H}_{2} \mathrm{O}_{2}+0.23$ & 0.45 & 0.20 & $4.84 \mathrm{E}-06$ & 0.76 & 0.759 & 1.55 \\
\hline 3.3 & $\mathrm{WB}=1.60 \mathrm{H}_{2} \mathrm{O}_{2}+0.35$ & 0.45 & 0.30 & 4.84E-06 & 1.14 & 0.759 & 2.33 \\
\hline
\end{tabular}


linear regression equations are given in Figure $4 \mathrm{a}$ and $\mathrm{b}$, respectively, with $\mathrm{C}$ conversion factors of 1.724, 2.2, and 3.3. Statistics of the regression models are presented in Table 1. Although the SOM content estimated by assigning different values for the $\mathrm{C}$ conversion factor varied widely at high organic matter contents, it did not show significant differ-
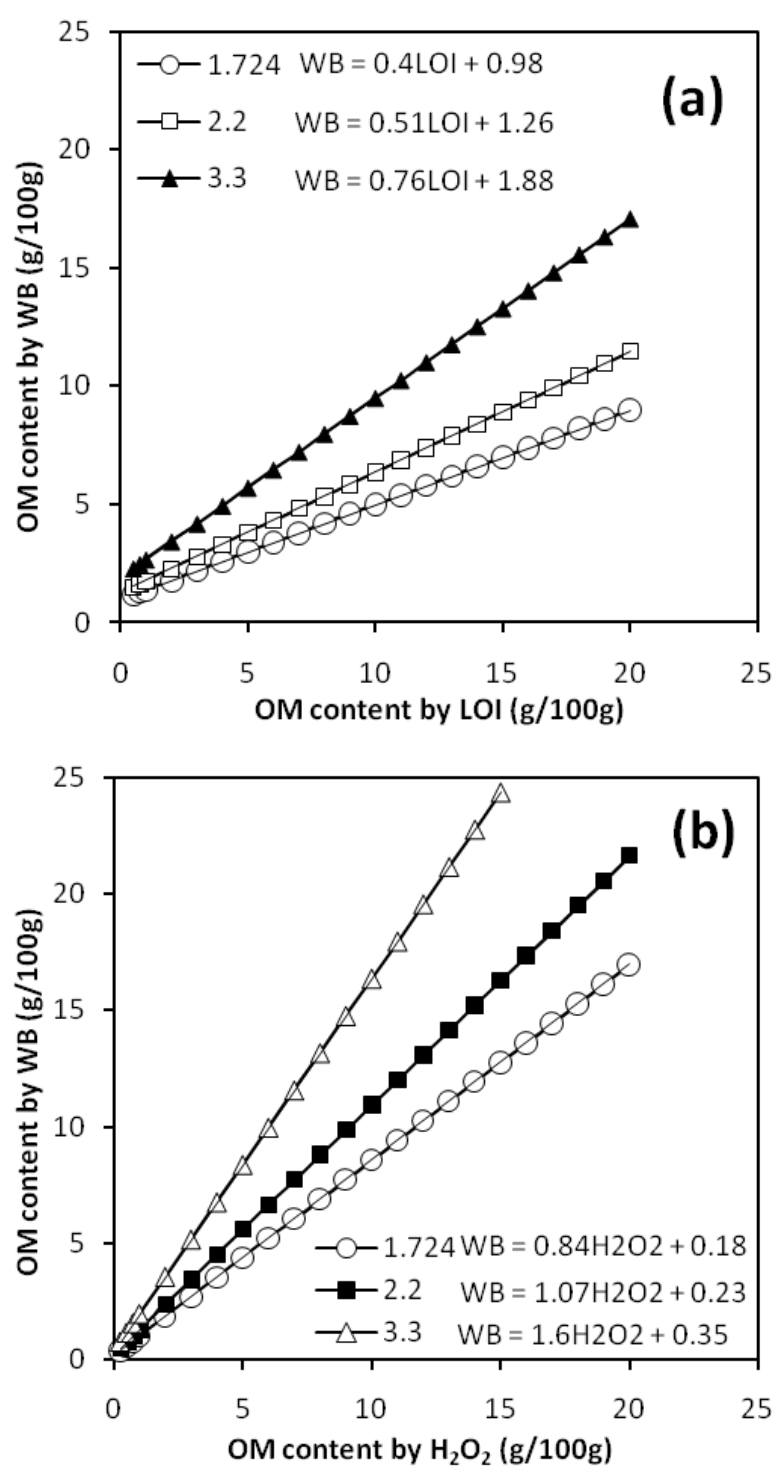

Figure 4: Relationsbetween the soil organic matter (SOM) contents as determined by (a) Walkley-Black (WB) and Loss on ignition (LOI) methods, and (b), Walkley-Black and hydrogen peroxide $\left(\mathrm{H}_{2} \mathrm{O}_{2}\right)$ methods predicted using the linear regression models at $\mathrm{C}$ conversion factors of 1.724, 2.2, and 3.3 ences at SOM contents below 2 g/100 g. Figure 4 a shows that the SOM contents estimated by the WB were considerably lower compared with those estimated by the LOI for $\mathrm{C}$ conversion factor of 1.724 and 2.2. The SOM content by these two methods were relatively comparable when 3.3 was used as the $\mathrm{C}$ conversion factor. In contrast, the SOM contents predicted by $\mathrm{WB}$ and $\mathrm{H}_{2} \mathrm{O}_{2}$ were fairly comparable at $\mathrm{C}$ conversion factor of 2.2. As reported by Nelson and Sommers (1982), the most appropriate values of the $\mathrm{C}$ conversion factor for converting organic $\mathrm{C}$ to organic matter in the surface and sub-surface soils are reported to be 1.9 to 2.5 , respectively.

The LOI is an alternative cost-effective method that does not include environmental threats or health hazards. However, there are some concerns on the accuracy and precision of the results for this technique considering the unexpected remains and losses during high-temperature burning. Gravimetric calculation related with the weight loss on combustion in the furnace may be an under or overestimate for the SOM content depending on the materials present in the soils. At low temperatures around $360^{\circ} \mathrm{C}$, complete burning of organic matter would not take place giving lower values than the actual SOM content. Alternatively, the temperatures above $440^{\circ} \mathrm{C}$ causes loss of structural water in clay lattices and potential volatilization of carbonates in calcareous soils, contributing to the weight loss and altering the result leading to an overestimation in organic matter content. Many studies in literature recommended maintaining a temperature level around $400^{\circ} \mathrm{C}$ to avoid thermal breakdown of carbonates and structural water in clays and hydrated salts. The method is also perceived to give variable results due to errors introduced through sample handling and the conditions within the muffle furnace (Goldin, 1987). A new LOI method has been introduced to address these critical issues using an apparatus called the Thermogravimetric analyzer (Pallasser et al., 2013). 
The $\mathrm{H}_{2} \mathrm{O}_{2}$ method does not involve the use of an empirical conversion factor and burning at too high or too low temperature that would cause errors in final calculations of SOM contents. However, the removal of the organic matter was not complete with $\mathrm{H}_{2} \mathrm{O}_{2}$. Samples may be heated to $90^{\circ} \mathrm{C}$ during peroxide addition to increase the speed and completeness of the peroxide digestion. Robinson (1922) reported findings on the use of hydrogen peroxide for determining SOM content with various kinds of organic matter. However, materials such as cotton fiber and crude fiber from straw are not decomposed by hydrogen peroxide, whereas humus or organic matter which had been extracted from soils by ammonia was completely decomposed (Robinson and Jones, 1925).

\section{CONCLUSIONS}

The determination of total organic carbon is an essential part of any site characterization or ecological assessment since its presence or absence can markedly influence how chemicals will react in the soil or sediment. There are numerous methods and variations of the methods for the identification and quantitation of TOC. In this study, we provided a comparison of the organic matter contents determined by $\mathrm{WB}, \mathrm{H}_{2} \mathrm{O}_{2}$, and LOI methods.

Except at very low organic matter contents, LOI method provided the highest, or comparably similar, organic matter contents with $\mathrm{H}_{2} \mathrm{O}_{2}$ method and WB method. The LOI method provided the highest or comparably similar SOM content with the $\mathrm{H}_{2} \mathrm{O}_{2}$ and the WB methods except at very low SOM contents. Use of $\mathrm{C}$ conversion factors 2.2 and 3.3 made SOM content estimated by WB method closer to values obtained by $\mathrm{H}_{2} \mathrm{O}_{2}$ and LOI methods, respectively. As the SOM is formed by the breakdown of plant and animal matter and constitutes a complicated mixture of many different compounds, it should be noted that there is no analytical test which can provide an absolute measure of organic matter.
Considering the cost of analysis and the high labor requirement in the $\mathrm{H}_{2} \mathrm{O}_{2}$ and WB methods, it appeared that the LOI method is the most suitable for analyzing the organic matter contents of soils, simply and rapidly, for a wide range of SOM levels.

\section{ACKNOWLEDGEMENT}

This work was financially supported by the annual research fund, Faculty of Agriculture, University of Ruhuna, and Postgraduate Research Grant 2015/2016, University of Ruhuna.

\section{REFERENCE}

Ball DE 1964 Loss-on-ignition as an estimate of organic matter and organic carbon in non-calcareous soils. J. Soil Science 15: 84-92.

Belpomme D, Irigaray P, Hardell L, Clapp R, Montagnier L, Epstein S and Sasco AJ 2007 The multitude and diversity of environmental carcinogens. Environmental Research 105(3): 414-429.

Ben-Dor E and Banin A1989 Determination of organic matter content in arid zone soils using a simple "loss-on-ignition" method. Communications in Soil Science and Plant Analysis 20: 1675-1695.

Bertucci JJ and Salvador SJ 1992 Microbiology of Sludge. In Lue-Hing C, Zenz DR and Kuchenrither R (Eds.) Municipal Sewage Sludge Management: Processing, Utilization and Disposal. Water quality management library, Vol. 4.Technomic Publishing Company, Inc. Lancaster, Pennsylvania.

Brady NC and Weil RR 2010 Elements of the nature and properties of soils.3rd Ed. Pearson Prentice Hall. Upper Saddle River, NJ. 
Davies BE 1974 Loss-on-ignition as an estimate of soil organic matter. Soil Science Society of America. Proceedings, 38:150 -151 .

Eash NS, Sauer TJ, O'Dell D, and Odoi E 2015 Soil biological properties. In Soil Science Simplified (6th Ed.). John Wiley \& Sons. Inc., Hoboken, New Jersey, USA Pp. 35-55.

Goldin A 1987 Reassessing the use of loss-on -ignition for estimating organic matter content in noncalcareous soils. Comm. Soil Science and Plant Analysis 18: 1111 $-1116$.

Howard PJA and Howard DM 1990 Use of organic carbon and loss-on-ignition to estimate soil organic matter in different soil types and horizons. Biol. Fertil. Soils 9: 306-310.

Kimble JM, Lal R, and Follett RF 2000 Methods for assessing soil $\mathrm{C}$ pools. In: Lal $\mathrm{R}$, Kimble JM, Follett RF and Stewart BA (Eds.) Assessment methods for soil carbon. CRC press LLC, Florida. Pp. 3-12.

Leelamanie DAL and Karube J 2009 Effects of hydrophobic and hydrophilic organic matter on the water repellency of model sandy soils. Soil Sci. Plant Nutr. 55(4): 462-467.

Leelamanie DAL and Karube J 2014a Surface hydrophobicity of Japanese Andisol and its behavior upon exposure to heat. Soil Sci. Soc. Am. J. 78:761-766.

Leelamanie DAL and Karube J 2014b Water stable aggregates of Japanese Andisol as affected by hydrophobicity and drying temperature. J. Hydrol. Hydromech. 62 (2): 97-100.

Leelamanie DAL, Karube J and Samarawickrama UI 2013 Stability analysis of aggregates in relation to the hydrophobic- ity of organic manure for Sri Lankan Red Yellow Podzolic soils. Soil Sci. Plant Nutr. 59(5): 683-691.

Mylavarapu RS, d'Angelo W, Wilkinson N, Moon D 2014 UF/IFAS extension soil testing laboratory (ESTL) analytical procedures and training manual. Circular 1248 Soil and Water Science Department, University of Florida. Available at http://edis.ifas.ufl.edu/pdffiles/SS/ SS31200.pdf, verified June 30, 2016.

Nelson DW and Sommers LE 1982 Total carbon, organic carbon, and organic matter. In: Methods of soil analysis. Part 2.Chemical and microbiological properties. American Society of Agronomy, Soil Science Society of America, Madison, WI, Pp. 539-579.

Pallasser R, Minasny Band McBratney AB 2013 Soil carbon determination by thermogravimetrics. Peer J, 1, e6. https:// dx.doi.org/10.7717/peerj.6.

Perie C, Ouimet R 2007 Organic carbon, organic matter and bulk density relationships in boreal forest soils. Can. J. Soil Sci. 88: 315-325.

Prusty BAK and Azeez PA 2005 Humus: The natural organic matter in the soil system. J. Agril. Res. \& Dev. 1: 1-12.

Ratnayake R, Seneviratne G, and Kulasooriya SA 2007 Modified Method of Weight Loss on Ignition to Evaluate Soil Organic Matter Fractions. International Journal of Soil Science 2:69-73.

Robinson GW 1922 Note on the mechanical analysis of humus soils. J. Agri. Sci. [England] 12: 287-291.

Robinson GW and Jones JO 1925A method for determining the degree of humification of soil organic matter. The Journal of Agricultural Science 15(1): 26-29. 
Rowell MJ 2000 Measurement of soil organic matter: A compromise between efficacy and environmental friendliness. Agricola 2000, 66-69.

Schnitzer M 1978Humic substances: chemistry and reactions. In: Soil Organic Marter (Eds M. Schnitzer \& S.U. Khan), pp. 1-64. Elsevier, Amsterdam.

Velichko AA, Borisova OK, Zelikson EM, and Morozova TD 2010 Dynamics of carbon storage in phyto mass and soil humus in Northern Eurasia during the last climatic macrocycle. Global and Planetary Change. 72: 257-64.

Walkley A and Black IA 1934 An examination of Degtjareff method for determining soil organic matter and a proposed modification of the chromic acid titration method. Soil Sci. 37:29-37. 